\title{
Country's Development as a Determinant of Early-Stage Entrepreneurial Activity
}

\author{
Miha Marič ${ }^{1}$, Jasmina Žnidaršič ${ }^{1}$, Miha Uhan ${ }^{2}$, Vlado Dimovski ${ }^{2}$, Marko Ferjan ${ }^{1}$, \\ Maja Djurica ${ }^{3}$, Mitja Jeraj $^{4}$, Matej Janežic ${ }^{5}$
}

\author{
${ }^{1}$ Faculty of Organizational Sciences, University of Maribor, Kidričeva 55a, 4000 Kranj, Slovenia, \\ miha.maric@fov.uni-mb.si, jasmina.pavlin@fov.uni-mb.si, marko.ferjan@fov.uni-mb.si \\ ${ }^{2}$ Faculty of Economics, University of Ljubljana, Kardeljeva ploščad 17, 1000 Ljubljana, Slovenia, \\ miha.uhan@ef.uni-lj.si, vlado.dimovski@ef.uni-lj.si \\ ${ }^{3}$ Belgrade Business School, 73 Kraljica Marija Street, 1000 Belgrade, Serbia, maja.djurica@bbs.edu.rs \\ ${ }^{4}$ JP Projekt, d.o.o., Trata XIV 6, 1330 Kočevje, Slovenia \\ ${ }^{5}$ National Institute of Chemistry, Hajdrihova 19, 1001 Ljubljana, Slovenia
}

\begin{abstract}
Our study is built on the dependence of early-stage entrepreneurial activity on GDP per capita, GDP real growth rate, unemployment rate, inflation rate, investments and public debt of different countries. We divide the early-stage entrepreneurial activity into necessity-driven and improvement-driven opportunistic entrepreneurial activity. To establish the dependencies we have conducted the regression analyses. Our three main findings are: (a) early-stage entrepreneurial activity does depend on our predictors; (b) necessity-driven entrepreneurial activity is negatively correlated to country's development; and (c) improvement-driven opportunistic entrepreneurial activity is positively correlated to country's development.
\end{abstract}

Keywords: entrepreneurship, early-stage entrepreneurial activity, economic development indicators

\section{Introduction}

Country's development has been a key aim of every country and therefore an interesting topic for researchers in the field of entrepreneurship and macroeconomics for quite some time. Entrepreneurial activity is an important part of country's development. We also believe that country's development, in turn, has effect on the development of early-stage entrepreneurial activity of its residents. In our research we distinguish between the necessity-driven early-stage entrepreneurial activity and improvement-driven opportunistic early-stage entrepreneurial activity. We have used six indicators of economic development for the selected countries: the GDP per capita, the GDP real growth rate, the unemployment rate, the inflation rate, investments and public debt. We tested our hypotheses if and to what extend necessitydriven entrepreneurial activity and improvement-driven opportunistic entrepreneurial activity is effected by those six predictors.

Based on our results we have concluded that the early-stage entrepreneurial activity does depend on our predictors. Results of our research also indicate that GDP per capita and the unemployment rate have the highest and not always positive correlations. We suggest at the end that entrepreneurial activity plays an important role especially in the long term and not as much in the short term.

The structure of the contribution is based on six parts where the introduction is followed by the theoretical background on country's development and entrepreneurship. This is followed by description of the methodology used for the contribution and discussion of the results of our study with conclusions.

\section{Entrepreneurship and country's economic development}

The importance of entrepreneurship has been recognized by economics since the beginning of the 18th century, at the microeconomic as well as at the macroeconomic levels (Minniti, Lévesque, 2008). Since then it has been increasingly gaining respect from the research com-

Received: $4^{\text {th }}$ April 2013; revised: $3^{\text {rd }}$ May 2013; accepted $17^{\text {th }}$ May 2013 
munity as a field of scholarly study as well as a practical application worldwide (Ma and Tan, 2006). Both the causes and consequences of entrepreneurship are a matter of extensive scientific debate as well as of great policy importance (Verheul et al., 2001). Governments increasingly consider entrepreneurship and innovation as the cornerstones of a competitive national economy (OECD report, 2008). Entrepreneurship is becoming one of the explicit parts of the economy in EU (European Commission, 2009) as well as in the other world countries (Bednarzik, 2000; Venkataraman, 2004).

Entrepreneurship is a complex phenomenon that spans a variety of contexts. A variety of definitions of entrepreneurship exists in the literature which reflect this complexity (Bosma et al., 2009) and no single definition has been generally agreed upon. However, entrepreneurship is usually defined as an "economic system" that consists of three components: (1) entrepreneurs, who desire to achieve their goals of economic survival and advancement; (2) the social constitution, that the entrepreneur's right of free enterprise is granted; and (3) the government, that has the ability to adjust the economic institutions that can work to protect each individual entrepreneur and to stimulate entrepreneurs' motive to achieve toward fostering of economic development and growth (Lowrey, 2003). Ma and Tan (2006) stress the four major components of entrepreneurship in their 4-P framework of entrepreneurship: "Pioneer", denoting the entrepreneur as an innovator or champion for innovation; "Perspective", denoting the entrepreneurial mindset; "Practice", denoting the entrepreneurial activities; and "Performance", denoting the outcome or result of entrepreneurial actions and activities. The OECD-Eurostat approach has combined the conceptual definitions of entrepreneurship with (available) empirical indicators and established following definitions (OECD report, 2008):

- Entrepreneurs are those persons (business owners) who seek to generate value through the creation or expansion of economic activity, by identifying and exploiting new products, processes or markets.

- Entrepreneurial activity is enterprising human action in pursuit of the generation of value through the creation or expansion of economic activity, by identifying and exploiting new products, processes or markets.

- Entrepreneurship is the phenomenon associated with entrepreneurial activity.

Early-stage entrepreneurial activity is defined (Hessels et $a l ., 2007$ ) as the entrepreneurial activity of the adult population (18-64 years old) that is either actively involved in starting a new venture (nascent entrepreneur) or the owner/manager of a business that is less than 42 months old (young business entrepreneur).

As noted by Hessels et al. (2007), at the micro level people may have different motives for becoming selfemployed. Some people mainly start a new business to exploit a perceived business opportunity. These people usually elect to start a business as one of several possible career options. This is for example the case when people choose to become an entrepreneur because they want to be their own boss, to realize a dream or to try and earn more money than in wage employment. This is commonly referred to as opportunity-based entrepreneurship. Other people are pushed into entrepreneurship because all other options for work are either absent or unsatisfactory. Entrepreneurship then is the last resort to work and income. This is for example the case if someone is unemployed and is not able to find a paid job. Since this type of entrepreneurship is necessity driven it is commonly referred to as necessity-based entrepreneurship. However, necessity-based entrepreneurship does not mean Dejardin's (2000) rent-seeking behaviour with negative social consequences (corruption, stealing, bribery etc.). There is a clear variation in the distribution of opportunity and necessity entrepreneurship across countries. As a country's level of per capita income rises, its percentage of opportunity entrepreneurship also goes up (Acs et al., 2004).

Global Entrepreneurship Monitor (GEM) has demonstrated that entrepreneurial activity is associated with national economic growth (Bosma et al., 2009). Witt (2000) claims that entrepreneurial venture is the backbone of persistent restructuring of modern economies. Chepurenko, Gabelko and Obraztsova (2011) claim that entrepreneurship is understood since Schumpeter as the driving motor of economic progress of nations. It is widely recognized that the supply of entrepreneurship is important for economic growth, innovation and job creation (Audretsch and Keilbach, 2007, Henrekson, 2005, Lee et al., 2013; Verheul et al., 2001, Wong et al., 2005). Cowling and Bygrave (2002) argue that small businesses make an important contribution to the success of a country's economy, because they are creators of jobs, they innovate, and they spot and exploit new opportunities. Further, Rasmussen and Sørheim (2006) claim that entrepreneurship, through the creation of new endeavour, is a major engine of economic growth. Similar, Thurik (2003) argues that there is both conceptual and empirical evidence that entrepreneurship fosters growth. Audretsch and Keilbach (2007) claim that entrepreneurship capital has a three-fold impact on economic growth: it facilitates knowledge spillovers, injects new competition in the input market for ideas, and enhances regional diversity, all of which are hypothesized to contribute to economic growth. Mueller (2006) also found out in his research that regions with a higher level of entrepreneurship experience greater economic performance. In particular, new firm formation in innovative industries is an important mechanism to commercialize knowledge, which is important for economic growth.

Many authors also claim that entrepreneurship reduces unemployment. Faria, Cuestas and Gil-Alana (2009) argue that when unemployment is high, more people create new businesses and successful new firm startups create new job which leads in reducing unemployment. Moreover, unemployment rate can stimulate 
start-up activity of self-employment on the one hand, and on the other hand a higher rate of self-employment may indicate increased entrepreneurial activity reducing unemployment in subsequent period of time. These two effects have resulted in considerable ambiguities about the interrelationship between unemployment and entrepreneurial activity (Thurik et al., 2008). The response to unemployment or lack of outside alternatives in the labour market can be the individual's decision to start a new business (Cowling and Bygrave, 2002). Van der Sluis et al. (2005) claim that entrepreneurs generate a substantial part of national income and employment in most countries. Small enterprises form a large, flexible buffer between salaries employment and incorporated business. Entrepreneurship may also generate benefit for society through the development and maintenance of human and social capital that occur when entrepreneurial activity takes place.

Yu (1998) argues that the economic success is largely attributable to the dynamics of adaptive entrepreneurs who are alert to opportunities and exploit them, maintain a high degree of flexibility in their production and respond rapidly to change. He highlighted the important role of adaptive entrepreneurship for a country and the importance of the entrepreneurial approach to economic problems. He also argues that any policy recommendation on economic development should be based on analysis that incorporates entrepreneurship, the engine of economic growth. There are some important issues as policy implications and the entrepreneurial platform in order to accelerate entrepreneurship in each country. For example, a country with a high tax burden and a strong welfare state is likely to be a country with a weak entrepreneurial culture (Henrekson, 2005).

Adelman and Yeldan (2000) argue that the economic development of a country has to combine five elements: self-sustaining growth, structural change in patterns of production, technological upgrading, social, political and institutional modernization and widespread improvement in the human condition. Even though this aspect of economic development has seen a lot of conflicting views in the past, the real GDP per capita (corrected for inflation) is generally used as the core indicator in judging the position of the economy of a country over time or relative to that of other countries (Van den Bergh, 2009).

As evident above, entrepreneurship seems to be positively affecting economic growth. Specifically, Acs and Varga (2005) discovered that necessity entrepreneurship has no effect on economic development while opportunity entrepreneurship has a positive and significant effect. The causal relationship is, however, according to Bosma and Schutjens (2007) still a complex one since the reversed relationship is also well-documented: welldeveloping regions or nations attract more entrepreneurs (Reynolds et al., 1994). Economic growth can either have a positive (Storey, 1999; Carree et al., 2002) or a negative (Kuznetz, 1966; Schultz, 1990; Bregger, 1996; Carree et al., 2002) impact on the level of entrepreneur- ship, depending on the stage of economic development and on the intermediate factors through which economic growth exerts influence on entrepreneurship (Verheul et al., 2001).

\section{Methodology}

\subsection{Hypotheses}

We are going to test the following three hypotheses which are based on the literature review above:

H1: Where there is a high country's development, there will be a higher early-stage entrepreneurial activity.

$\mathrm{H} 2$ : Where there is a high country's development, there will be a lower necessity-driven entrepreneurial activity.

H3: Where there is a high country's development, there will be a higher improvement-driven opportunistic entrepreneurial activity.

\subsection{Variables}

The variables used in our research are the following:

A “GDP p.c. (PPP in \$)" is the GDP on a purchasing power parity basis divided by population as of 1 July for the same year (CIA - The World Factbook).

B "GDP real growth rate" gives us GDP growth on an annual basis adjusted for inflation and expressed as a percent (CIA - The World Factbook).

$\mathrm{C}$ "Unemployment rate" is the percent of the labour force that is without jobs. Unemployment and unemployment rate were already defined in the theoretical platform (CIA - The World Factbook).

D "Inflation rate (consumer prices)" furnishes the annual percent change in consumer prices compared with the previous year's consumer prices (CIA - The World Factbook).

E “Investment (gross fixed)" records total business spending on fixed assets, such as factories, machinery, equipment, dwellings, and inventories of raw materials, which provide the basis for future production. It is measured gross of the depreciation of the assets, i.e., it includes investment that merely replaces worn-out or scrapped capital (CIA - The World Factbook). It is expressed as a percentage of the GDP of a certain country.

F "Public debt" records the cumulative total of all government borrowings less repayments that are denominated in a country's home currency. Public debt should not be confused with external debt, which reflects the foreign currency liabilities of both the private and public sector and must be financed out of foreign exchange earnings (CIA - The World Factbook). It is expressed as a percentage of the GDP of a certain country.

G "Early-stage entrepreneurial activity" is the percentage of 18-64 population who are either a nas- 
cent entrepreneur (actively involved in setting up a business they will own or co-own; this business has not paid salaries, wages, or any other payments to the owners for more than three months) or ownermanager of a new business (owning and managing a running business that has paid salaries, wages, or any other payments to the owners for more than three months, but not more than 42 months) (Bosma and Levie, 2010).

$\mathrm{H}$ "Necessity-driven entrepreneurial activity (relative prevalence)" is the percentage of those involved in early-stage entrepreneurial activity (as defined above) who are involved in entrepreneurship because they had no other option for work (Bosma and Levie, 2010).

I "Improvement-driven opportunistic entrepreneurial activity (relative prevalence)" is the percentage of those involved in early-stage entrepreneurial activity (as defined above) who (i) claim to be driven by opportunity as opposed to finding no other option for work; and (ii) who indicate the main driver for being involved in this opportunity is being independent or increasing their income, rather than just maintaining their income (Bosma and Levie, 2010).

\subsection{Data Collection}

Countries in this research are from the GEM yearly report in which they explain and measure different aspects and levels of entrepreneurship for various selected countries. Based on the selected development indicators, we have selected 52 out of 54 countries from the report to conduct our study $(n=52)$. All of the data are for the year 2009 . Table 1 presents the countries' development indicators that we have selected for this study. We can see that the GDPs per capita (PPP in \$) were between \$2,500 and $\$ 59,300$ (average $\$ 20,425$ ), the GDP real growth rates were between $-17.8 \%$ and $8.7 \%$ (average $-1.944 \%$ ), the unemployment rates in these countries were between $2.4 \%$ and $40.0 \%$ (average $10.877 \%$ ), the inflation rates (consumer prices) were between $-1.3 \%$ and $27.3 \%$ (average $3.723 \%$ ), the investments (gross fixed) were between $12.5 \%$ and $42.6 \%$ (average $22.022 \%$ ) and that the public debt was between $6.9 \%$ and $192.1 \%$ (average $53.738 \%$ ).

Table 1: GDP per capita PPP, GDP real growth rates, unemployment rates, inflation rates, investments and public debt by country for the year $2009(n=52)$

\begin{tabular}{|l|c|c|c|c|c|c|}
\hline Country & $\begin{array}{c}\text { GDP p.c. } \\
\text { (PPP in \$) }\end{array}$ & $\begin{array}{c}\text { GDP real } \\
\text { growth rate }\end{array}$ & $\begin{array}{c}\text { Unemployment } \\
\text { rate }\end{array}$ & $\begin{array}{c}\text { Inflation rate } \\
\text { (consumer } \\
\text { prices) }\end{array}$ & $\begin{array}{c}\text { Investment } \\
\text { (gross fixed) } \\
\text { (\% of GDP) }\end{array}$ & $\begin{array}{c}\text { Public debt } \\
\text { (\% of GDP) }\end{array}$ \\
\hline Algeria & 7,100 & 3.4 & 12.4 & 4.1 & 26.8 & 10.7 \\
\hline Argentina & 13,800 & -2.5 & 9.6 & 7.7 & 21.0 & 49.1 \\
\hline Belgium & 36,600 & -3.4 & 8.3 & .0 & 24.2 & 99.0 \\
\hline Bosnia and Herzegovina & 6,300 & -2.9 & 40 & .6 & n.a. & 43.0 \\
\hline Brazil & 10,200 & .1 & 7.4 & 4.2 & 17.0 & 46.8 \\
\hline Chile & 14,700 & -1.5 & 10 & 1.7 & 20.5 & 9.0 \\
\hline China & 6,500 & 8.7 & 4.3 & -.8 & 42.6 & 18.2 \\
\hline Colombia & 9,200 & -.1 & 12 & 3.0 & 23.2 & 46.1 \\
\hline Croatia & 17,600 & -5.2 & 16.1 & 2.4 & 22.8 & 61.0 \\
\hline Denmark & 36,200 & -4.3 & 4.3 & 1.3 & 20.0 & 38.5 \\
\hline Dominican Republic & 8,200 & -.3 & 15.1 & 1.4 & 16.6 & 41.5 \\
\hline Ecuador & 7,300 & -2.0 & 9.8 & 4.3 & 27.5 & 20.2 \\
\hline Finland & 34,900 & -7.6 & 8.5 & .0 & 19.0 & 41.4 \\
\hline France & 32,800 & -2.1 & 9.7 & .1 & 20.8 & 79.7 \\
\hline Germany & 34,200 & -5.0 & 8.2 & .0 & 18.9 & 77.2 \\
\hline Greece & 32,100 & -2.5 & 8.9 & 1.0 & 15.6 & 108.1 \\
\hline Guatemala & 5,200 & -.5 & 3.2 & 2.2 & 16.9 & 32.7 \\
\hline Hong Kong & 42,700 & -3.1 & 5.9 & -.3 & 17.6 & 18.1 \\
\hline
\end{tabular}




\begin{tabular}{|c|c|c|c|c|c|c|}
\hline Country & $\begin{array}{l}\text { GDP p.c. } \\
\text { (PPP in \$) }\end{array}$ & $\begin{array}{l}\text { GDP real } \\
\text { growth rate }\end{array}$ & $\begin{array}{c}\text { Unemployment } \\
\text { rate }\end{array}$ & $\begin{array}{l}\text { Inflation rate } \\
\text { (consumer } \\
\text { prices) }\end{array}$ & $\begin{array}{l}\text { Investment } \\
\text { (gross fixed) } \\
(\% \text { of GDP) }\end{array}$ & $\begin{array}{l}\text { Public debt } \\
\text { (\% of GDP) }\end{array}$ \\
\hline Hungary & 18,800 & -6.4 & 11 & 2.0 & 19.0 & 78.0 \\
\hline Iceland & 39,800 & -6.3 & 8.2 & 12.0 & 18.6 & 95.1 \\
\hline Iran & 12,900 & 2.6 & 11.8 & 16.8 & 27.7 & 19.4 \\
\hline Israel & 28,400 & -.3 & 8 & 3.9 & 16.0 & 78.0 \\
\hline Italy & 30,200 & -5.0 & 7.5 & .6 & 19.2 & 115.2 \\
\hline Jamaica & 8,300 & -4.0 & 14.5 & 8.6 & 22.2 & 131.7 \\
\hline Japan & 32,600 & -5.7 & 5.6 & -1.3 & 20.2 & 192.1 \\
\hline Jordan & 5,300 & 3.1 & 13.5 & 1.7 & 31.2 & 69.9 \\
\hline Latvia & 14,500 & -17.8 & 16.6 & 3.3 & 26.2 & 32.5 \\
\hline Lebanon & 11,500 & 7.0 & 9.2 & 3.4 & 21.5 & 156.0 \\
\hline Malaysia & 14,700 & -2.8 & 5 & .4 & 18.2 & 47.8 \\
\hline Netherlands & 39,000 & -4.3 & 5 & 1.2 & 19.4 & 62.2 \\
\hline Norway & 59,300 & -1.1 & 3.2 & 2.3 & 20.5 & 60.2 \\
\hline Panama & 11,900 & 2.4 & 7.1 & 2.3 & 26.7 & 49.5 \\
\hline Peru & 8,600 & 1.0 & 9 & 1.2 & 20.8 & 26.1 \\
\hline Republic of Korea & 27,700 & -.8 & 4.1 & 2.8 & 28.2 & 28.0 \\
\hline Kingdom of Tonga & 4,600 & -.5 & 13 & 5.9 & & \\
\hline Romania & 11,500 & -6.9 & 7.6 & 5.0 & 25.5 & 20.0 \\
\hline Russia & 15,200 & -7.9 & 8.9 & 11.9 & 20.0 & 6.9 \\
\hline Saudi Arabia & 20,300 & -.6 & 11.6 & 5.0 & 24.2 & 20.3 \\
\hline Serbia & 10,400 & -4.6 & 18.8 & 6.6 & 33.1 & 31.3 \\
\hline Slovenia & 28,200 & -6.2 & 9.4 & .8 & 23.7 & 31.4 \\
\hline South Africa & 10,000 & -1.9 & 24 & 7.2 & 20.6 & 35.7 \\
\hline Spain & 33,700 & -3.6 & 18.1 & -.8 & 26.6 & 50.0 \\
\hline Switzerland & 41,600 & -1.8 & 3.7 & -.6 & 21.1 & 43.5 \\
\hline Syria & 4,700 & 2.2 & 9.2 & 3.8 & 21.7 & 32.3 \\
\hline Tunisia & 8,000 & .7 & 15.7 & 3.7 & 25.9 & 47.2 \\
\hline United Arab Emirates & 41,800 & -4.0 & 2.4 & 1.5 & 28.9 & 47.2 \\
\hline United Kingdom & 35,400 & -4.3 & 8 & 2.1 & 15.0 & 68.5 \\
\hline United States & 46,400 & -2.4 & 9.4 & -.7 & 12.5 & 52.9 \\
\hline Uruguay & 12,600 & .6 & 7.9 & 7.3 & 15.5 & 58.7 \\
\hline Venezuela & 13,200 & -1.5 & 10.9 & 27.3 & 18.3 & 19.4 \\
\hline $\begin{array}{l}\text { West Bank and Gaza } \\
\text { Strip }\end{array}$ & 2,900 & 7.0 & 19 & 9.9 & n.a. & n.a. \\
\hline Yemen & 2,500 & 3.8 & 35 & 3.6 & 19.9 & 39.6 \\
\hline
\end{tabular}


Table 2 presents us the entrepreneurial activity in the selected countries. We can see from it that the earlystage entrepreneurial activity was between 3.3 and 26.84 (average 10.308), the necessity-driven entrepreneurial activity was between 7 and 48 (average 25.71) and that the improvement-driven opportunistic entrepreneurial activity was between 16 and 79 (average 47.25) for the selected countries.

Table 2: Early-stage entrepreneurial activity and its division to necessity-driven and improvement-driven entrepreneurial activity by country for the year $2009(n=52)$

\begin{tabular}{|c|c|c|c|}
\hline Country & $\begin{array}{c}\text { Early-stage } \\
\text { entrepreneurial } \\
\text { activity }\end{array}$ & $\begin{array}{l}\text { Necessity-driven entrepreneurial } \\
\text { activity }\end{array}$ & $\begin{array}{l}\text { Improvement-driven oppor- } \\
\text { tunistic entrepreneurial } \\
\text { activity }\end{array}$ \\
\hline Algeria & 16.7 & 47 & 37 \\
\hline Argentina & 14.7 & 9 & 55 \\
\hline Belgium & 3.5 & 39 & 20 \\
\hline Bosnia and Herzegovina & 4.4 & 39 & 48 \\
\hline Brazil & 15.3 & 25 & 42 \\
\hline Chile & 14.9 & 48 & 29 \\
\hline China & 18.8 & 34 & 45 \\
\hline Colombia & 22.4 & 37 & 39 \\
\hline Croatia & 5.6 & 7 & 56 \\
\hline Denmark & 3.6 & 34 & 26 \\
\hline Dominican Republic & 17.5 & 32 & 43 \\
\hline Ecuador & 15.8 & 19 & 62 \\
\hline Finland & 5.2 & 14 & 67 \\
\hline France & 4.3 & 31 & 43 \\
\hline Germany & 4.1 & 26 & 47 \\
\hline Greece & 8.8 & 23 & 30 \\
\hline Guatemala & 26.8 & 19 & 49 \\
\hline Hong Kong & 3.6 & 24 & 45 \\
\hline Hungary & 9.1 & 10 & 58 \\
\hline Iceland & 11.4 & 35 & 35 \\
\hline Iran & 12 & 25 & 48 \\
\hline Israel & 6.1 & 14 & 57 \\
\hline Italy & 3.7 & 33 & 45 \\
\hline Jamaica & 22.7 & 30 & 62 \\
\hline Japan & 3.3 & 28 & 35 \\
\hline Jordan & 10.2 & 32 & 54 \\
\hline Latvia & 10.5 & 18 & 60 \\
\hline Lebanon & 15 & 25 & 44 \\
\hline Malaysia & 4.4 & 10 & 57 \\
\hline Netherlands & 7.2 & 9 & 74 \\
\hline
\end{tabular}




\begin{tabular}{|c|c|c|c|}
\hline Country & $\begin{array}{l}\text { Early-stage } \\
\text { entrepreneurial } \\
\text { activity }\end{array}$ & $\begin{array}{l}\text { Necessity-driven entrepreneurial } \\
\text { activity }\end{array}$ & $\begin{array}{l}\text { Improvement-driven oppor- } \\
\text { tunistic entrepreneurial } \\
\text { activity }\end{array}$ \\
\hline Norway & 8.5 & 24 & 59 \\
\hline Panama & 9.6 & 28 & 42 \\
\hline Peru & 20.9 & 45 & 37 \\
\hline Republic of Korea & 7 & 33 & 39 \\
\hline Republic of Tonga & 17.4 & 34 & 31 \\
\hline Romania & 5 & 29 & 37 \\
\hline Russia & 3.9 & 12 & 63 \\
\hline Saudi Arabia & 4.7 & 41 & 46 \\
\hline Serbia & 4.9 & 10 & 69 \\
\hline Slovenia & 5.4 & 33 & 38 \\
\hline South Africa & 5.9 & 16 & 41 \\
\hline Spain & 5.1 & 7 & 67 \\
\hline Switzerland & 7.7 & 37 & 43 \\
\hline Syria & 8.5 & 20 & 57 \\
\hline Tunisia & 9.4 & 9 & 79 \\
\hline United Arab Emirates & 13.3 & 16 & 43 \\
\hline United Kingdom & 5.7 & 23 & 55 \\
\hline United States & 8 & 22 & 57 \\
\hline Uruguay & 12.2 & 32 & 42 \\
\hline Venezuela & 18.7 & 37 & 33 \\
\hline $\begin{array}{l}\text { West Bank and Gaza } \\
\text { Strip }\end{array}$ & 8.6 & 35 & 16 \\
\hline Yemen & 24 & 47 & 37 \\
\hline
\end{tabular}

Source: Global Entrepreneurship Monitor, Global Report 2009 (Bosma and Levie, 2010)

\section{Results and discussion}

\subsection{Results}

We begin by constructing the frequency tables (Table 3 ) and the correlation matrix (Table 4) for the variables that we have used in our research.

In the following three tables we will use multiple regressions to analyse the relationships between a set of independent variables representing "Country's development" and each of the dependent variables. The regression analysis for the dependent variable "early-stage entrepreneurial activity" is portrayed in Table 5, for "necessity-driven entrepreneurial activity" in Table 6 and for "improvement-driven opportunistic entrepreneurial activity" in Table 7.
With the predictors that we have used to describe "Country's development" 32.7\% variance of "Earlystage entrepreneurial activity" is explained. "GDP p.c. (PPP in \$)" ( $\beta=-0.470)$ has the most influence. The second most influential predictor is "GDP real growth rate" $(\beta=0.303)$ which has a positive effect and is also statistically significant.

With the predictors that we have used to describe "Country's development" $34.7 \%$ variance of "Necessitydriven entrepreneurial activity" is explained. "GDP p.c. (PPP in $\$)$ " ( $\beta=-0.603)$ has the most influence and is also the only statistically significant predictor.

With the predictors that we have used to describe "Country's development" $39.2 \%$ variance of "Improvement-driven opportunistic entrepreneurial activity" is explained. "GDP p.c. (PPP in $\$)$ " $(\beta=0.505)$ 
Table 3: Frequency tables for the variables $(n=52)$

\begin{tabular}{|l|l|c|c|c|c|c|c|c|c|c|}
\hline \multicolumn{2}{|l|}{} & A & B & C & D & E & F & G & H & I \\
\hline \multirow{2}{*}{$\mathbf{n}$} & Valid & 52 & 52 & 52 & 52 & 49 & 50 & 52 & 52 & 52 \\
\cline { 2 - 11 } & Missing & 0 & 0 & 0 & 0 & 3 & 2 & 0 & 0 & 0 \\
\hline Mean & $20,425.000$ & -1.944 & 10.877 & 3.723 & 22.022 & 53.738 & 10.308 & 25.71 & 47.25 \\
\hline Median & $14,600.000$ & -2.050 & 9.200 & 2.300 & 20.800 & 46.450 & 8.550 & 25.50 & 45.00 \\
\hline Std. Deviation & $14,192.761$ & 4.3049 & 7.0516 & 4.9631 & 5.3504 & 37.500 & 6.2615 & 11.046 & 13.316 \\
\hline Minimum & $2,500.000$ & -17.8 & 2.4 & -1.3 & 12.5 & 6.9 & 3.3 & 7 & 16 \\
\hline Maximum & $59,300.000$ & 8.7 & 40.0 & 27.3 & 42.6 & 192.1 & 26.8 & 48 & 79 \\
\hline
\end{tabular}

Table 4: Pearson r Correlation Coefficients $(n=52)$

\begin{tabular}{|l|c|c|c|c|c|c|c|c|}
\hline & $\mathbf{A}$ & $\mathbf{B}$ & $\mathbf{C}$ & $\mathbf{D}$ & $\mathbf{E}$ & $\mathbf{F}$ & $\mathbf{G}$ & $\mathbf{H}$ \\
\hline $\mathbf{B}$ & $-.393^{* *}$ & & & & & & & \\
\hline $\mathbf{C}$ & $-.466^{* *}$ & .061 & & & & & & \\
\hline $\mathbf{D}$ & $-.320^{*}$ & .078 & .125 & & & & & \\
\hline $\mathbf{E}$ & $-.311^{*}$ & .239 & .084 & -.023 & & & & \\
\hline $\mathbf{F}$ & .269 & -.061 & -.103 & -.205 & -.256 & & & \\
\hline $\mathbf{G}$ & $-.527^{* *}$ & $.415^{* *}$ & .082 & .261 & .078 & -.137 & & \\
\hline $\mathbf{H}$ & $-.663^{* *}$ & .208 & $.369^{* *}$ & .260 & $.285^{*}$ & -.198 & $.308^{*}$ & \\
\hline $\mathbf{I}$ & $.648^{* *}$ & -.256 & $-.536^{* *}$ & -.203 & -.096 & $.305^{*}$ & $-.332^{*}$ & $-.733^{* *}$ \\
\hline
\end{tabular}

*. Correlation is significant at the 0.05 level (2-tailed).

**. Correlation is significant at the 0.01 level (2-tailed).

Table 5: Regression Analysis for the Dependent Variable “Early-stage entrepreneurial activity” ( $n=52)$ $R=0.641 ; R^{2}=0.411 ;$ Adj. $R^{2}=0.327$

\begin{tabular}{|l|c|c|c|c|c|}
\hline Predicators & \multicolumn{2}{|c|}{ Unstandardized Coefficients } & $\begin{array}{c}\text { Standardized } \\
\text { Coefficients }\end{array}$ & t & \multirow{2}{*}{ Sig. } \\
\cline { 1 - 3 } & $\mathbf{B}$ & Std. Error & Beta & & .000 \\
\hline (Constant) & 19.408 & 4.986 & & 3.893 & .005 \\
\hline GDP p.c. (PPP in \$) & .000 & .000 & -.470 & -2.984 & .026 \\
\hline GDP real growth rate & .451 & .195 & .303 & 2.315 & .839 \\
\hline Unemployment rate & -.030 & .148 & -.028 & -.205 & .421 \\
\hline $\begin{array}{l}\text { Inflation rate (consumer } \\
\text { prices) }\end{array}$ & .131 & .161 & .104 & .813 & .288 \\
\hline Investment (gross fixed) & -.165 & .153 & -.140 & -1.075 & .898 \\
\hline Public debt & -.003 & .021 & -.016 & -.129 & \\
\hline
\end{tabular}

Dependent Variable: Early-stage entrepreneurial activity 
Table 6: Regression Analysis for the Dependent Variable "Necessity-driven entrepreneurial activity" ( $n=52)$

$R=0.655 ; R^{2}=0.429 ;$ Adj. $R^{2}=0.347$

\begin{tabular}{|c|c|c|c|c|c|}
\hline \multirow[t]{2}{*}{ Predicators } & \multicolumn{2}{|c|}{ Unstandardized Coefficients } & \multirow{2}{*}{$\begin{array}{c}\begin{array}{c}\text { Standardized } \\
\text { Coefficients }\end{array} \\
\text { Beta } \\
\end{array}$} & \multirow{2}{*}{$\mathbf{t}$} & \multirow{2}{*}{ Sig. } \\
\hline & B & Std. Error & & & \\
\hline (Constant) & 28.442 & 8.585 & & 3.313 & .002 \\
\hline GDP p.c. (PPP in \$) & .000 & .000 & -.603 & -3.889 & .000 \\
\hline GDP real growth rate & -.190 & .336 & -.073 & -.565 & .575 \\
\hline Unemployment rate & .034 & .255 & .017 & .132 & .896 \\
\hline Inflation rate (consumer prices) & .159 & .278 & .072 & .573 & .570 \\
\hline Investment (gross fixed) & .241 & .264 & .117 & .913 & .366 \\
\hline Public debt & .002 & .036 & .008 & .067 & .947 \\
\hline
\end{tabular}

Dependent Variable: Necessity-driven entrepreneurial activity

Table 7: Regression Analysis for the Dependent Variable "Improvement-driven opportunistic entrepreneurial activity" ( $n=52)$ $R=0.684 ; R^{2}=0.468 ;$ Adj. $R^{2}=0.392$

\begin{tabular}{|l|c|c|c|c|c|}
\hline \multirow{2}{*}{ Predicators } & \multicolumn{2}{|c|}{ Unstandardized Coefficients } & \multirow{2}{*}{$\begin{array}{c}\text { Standardized } \\
\text { Coefficients }\end{array}$} & t & \multirow{2}{*}{ Sig. } \\
\cline { 1 - 3 } & B & Std. Error & Beta & & \multicolumn{2}{c|}{} \\
\hline (Constant) & 31.276 & 9.678 & & 3.232 & .002 \\
\hline GDP p.c. (PPP in \$) & .000 & .000 & .505 & 3.378 & .002 \\
\hline GDP real growth rate & -.212 & .378 & -.069 & -.559 & .579 \\
\hline Unemployment rate & -.487 & .287 & -.217 & -1.693 & .098 \\
\hline Inflation rate (consumer prices) & .075 & .313 & .029 & .240 & .811 \\
\hline Investment (gross fixed) & .352 & .297 & .146 & 1.182 & .244 \\
\hline Public debt & .065 & .041 & .190 & 1.576 & .123 \\
\hline
\end{tabular}

Dependent Variable: Improvement-driven opportunistic entrepreneurial activity

has the most influence and is also the only statistically significant predictor.

\subsection{Discussion}

Our research shows us that based on the data of the variables that we choose to represent country's economic development and the variables representing early-stage entrepreneurial activity we can conclude that country's development does affect early-stage entrepreneurial activity but not entirely as we have imagined.

Based on our research on the H1 hypothesis which states that where there is a high country's development, there will be a higher early-stage entrepreneurial activ- ity we can conclude that countries that have high GDP p.c. (PPP in \$) have a negative correlation to early-stage entrepreneurial activity, whereas the high GDP real growth rates have a positive correlation to early-stage entrepreneurial activity which can be seen from Table 4 and Table 5. For future research we suggest to divide the countries which are highly developed from those that are developing fast.

Our research confirms the $\mathrm{H} 2$ hypothesis which states that where there is a high country's development, there will be a lower necessity driven entrepreneurial activity. We can confirm this hypothesis because we can see from Table 4 that GDP p.c. (PPP in \$) is negatively correlated to necessity driven entrepreneurial activity whereas the unemployment rate is positively correlated 
to it. That means that countries with high GDP p.c. (PPP in \$) have low necessity driven entrepreneurial activity and high unemployment rates.

Our research confirms the $\mathrm{H} 3$ hypothesis which states that where there is a high country's development, there will be a higher improvement-driven opportunistic entrepreneurial activity. We can confirm this hypothesis because we can see from Table 4 that GDP p.c. (PPP in \$) is positively correlated to improvement-driven opportunistic entrepreneurial activity whereas the unemployment rate is negatively correlated to it. That means that countries with high GDP p.c. (PPP in \$) have high improvement-driven opportunistic entrepreneurial activity and low unemployment rates.

We suppose that the basic limitation to our work is in the part that we suggest for further research and that is the division between the countries' development. Otherwise we got the results that we have anticipated already from the literature review and personal logical reasoning which we stated in our hypotheses and later on confirmed.

Recently, a paper by Sohn and Lee (2013) has been published that proposed an early-stage entrepreneurial activity index that can predict the percentage of both nascent entrepreneur and new business owner using the variables related to entrepreneurial attitudes of the previous year. This index is also one of the possibilities for future research on and prediction of early-stage entrepreneurship, as it can be used to predict various aspects of entrepreneurial aspiration of the following year. Their proposed index is believed to have a very high prediction accuracy and is expected to provide effective policies to boost future entrepreneurial activity and aspiration.

Also, contrary to our macro view of the problem, Pete, Nagy, Györfy, Benyovszki and Petru (2010) have tackled the issue of early-stage entrepreneurial activity from a more micro-based perspective, analyzing the following influencing factors of the probability of becoming an early-stage entrepreneur in Romania: gender, age, education, household income, work status, network, opportunity perception, perception regarding the trust in own entrepreneurial skills, perception on the society's appreciation regarding the principle of equality in life standard, perception on the society's appreciation regarding the entrepreneurial career, and perception on the proper promotion of entrepreneurial successes by mass media. It is our recommendation for future work in this field to perform a study of early-stage entrepreneurial activity in relation to both micro and macro factors.

\section{Conclusion}

Entrepreneurial activity is an important part of country's development. Economic development is the goal that every country wants to achieve on a yearly basis on which it is measured. In our research we have used six indicators of economic development for the countries selected: the GDP per capita (PPP), GDP real growth rate, the unemployment rate, the inflation rate, investment and public debt. We confirmed our hypotheses almost completely with one small exception that we suggest to be careful of in further research, which is the division between highly developed and highly developing countries.

We believe that economic development plays an important role in early-stage entrepreneurial activity especially in the long term and also but not just as much in the short term. As we have concluded from our research, GDP p.c. and the unemployment rate have the highest and not always positive correlations.

\section{Literature}

Acs, Z. J., Arenius, P., Hay, M. \& Minniti, M. (2004). Global Entrepreneurship Monitor, 2004 Executive Report. Babson College and London Business School.

Acs, Z. J. \& Varga, A. (2005). Entrepreneurship, Agglomeration and Technological Change. Small Business Economics, 24 (3), 323334, http://dx.doi.org/10.1007/s11187-005-1998-4

Adelman, I. \& Yeldan, E. (2000). Is this the end of economic development? Structural Change and Economic Dynamics, 11 (1-2), 95-109, http://dx.doi.org/10.1016\%2FS0954349 X\%2899\%2900019-3

Audretsch, D. B. \& Keilbach, M. (2007). The localisation of entrepreneurship capital: Evidence from Germany. Papers in Regional Science, 86 (3), 351-365, http://dx.doi.org/10.1111\%2Fj.14355957.2007.00131.x

Bednarzik, R. W. (2000). Role of Entrepreneurship in US and European Job Growth. Monthly Labor Review, 123 (7), 3-16.

Bosma, N. \& Schutjens, V. (2007). Patterns of promising entrepreneurial activity in european regions. Tijdschrift voor Economische en Sociale Geografie, 98 (5), 675-686, http:// dx.doi.org/10.1111\%2Fj.1467-9663.2007.00433.x

Bosma, N., Acs, Z. J., Autio, E., Coduras, A. \& Levie, J. (2009). Global Entrepreneurship Monitor, 2008 Executive Report. Babson Park (MA): Babson College.

Bosma, N. \& Levie, J. (2010). Global Entrepreneurship Monitor, 2009 Global Report. Babson Park (MA): Babson College.

Bregger, J. E. (1996). Measuring self-employment in the United States. Monthly Labor Review, 119 (1\&2), 3-9.

Carree, M. A., van Stel, A., Thurik, A. R. \& Wennekers, A. R. M. (2002). Economic development and business ownership: an analysis using data of 23 OECD countries in the period 19761996. Small Business Economics, 19 (3), 271-290.

Chepurenko, A. Y., Gabelko, M. \& Obraztsova, O. (2011). EarlyStage Entrepreneurial Activity: An Explanatory Model for Cross-Country Comparisons (February 8, 2012). Higher School Of Economics Working Paper No. WP1/2011/04.

CIA - The World Factbook (2010). Last available January 24, 2013 https://www.cia.gov/library/publications/the-world-factbook/ rankorder/rankorderguide.html

Cowling, M. \& Bygrave, W. D. (2002). Entrepreneurship and Unemployment: Relationship between unemployment and entrepreneurship in 37 nations participating in the Global Entrepreneurship Monitor (GEM) 2002. Frontiers of Entrepreneurship Research 2003, 544-555.

Dejardin, M. (2000). Entrepreneurship and Economic Growth: An Obvious Conjunction? Introductory Discussion Paper Ref. IDS DP 2000-08, Indiana University, Bloomington. 
European Commission, The Official Site of European Commission. Last available January 24, 2013 at http://ec.europa.eu/index_ en.htm

Faria, J. R., Cuestas, J. C. \& Gil-Alana, L. A. (2009). Unemployment and entrepreneurship: A cyclical relation? Economics Letters, 105(3), 318-320, http://dx.doi.org/10.1016\%2Fj.econlet.2009.09.004

Henrekson, M. (2005). Entrepreneurship: a weak link in welfare state? Industrial and Corporate Change, 14 (3), 437-467, http:// dx.doi.org/10.1093\%2Ficc\%2Fdth060

Hessels, J., van Stel, A., Brouwer, P. \& Wennekers, S. (2007). Social security arrangements and early-stage entrepreneurial activity. Scales Research Reports, No H200708, EIM Business and Policy Research.

Kuznetz, S. (1966). Modern Economic Growth: Rate, Structure and Spread. New Haven: Yale University Press.

Lee, S.-H., Peng, M. W. \& Song, S. (2013). Governments, entrepreneurs, and positive externalities: A real options perspective. European Management Journal, 31 (4), 333-347, http://dx.doi. org/10.1016\%2Fj.emj.2013.01.006

Lowrey, Y., (2003). The entrepreneur and entrepreneurship: a neoclassical approach. Office of Advocacy, U.S. Small Business Administration Economic Research Working Paper. Last available January 24, 2013 at

http://papers.ssrn.com/sol3/papers.cfm?abstract_id $=744785$

Ma, H. \& Tan, J. (2006). Key components and implications of entrepreneurship: A 4-P framework. Journal of Business Venturing, 21 (5), 704-725, http://dx.doi.org/10.1016\%2Fj.jbusvent.2005.04.009

Minniti, M. \& Lévesque, M. (2008). Recent developments in the economics of entrepreneurship. Journal of Business Venturing, 23 (6), 603-612, http://dx.doi.org/10.1016\%2Fj.jbusvent.2008.01.001

Mueller P. (2006). Exploring the knowledge lter: How entrepreneurship and university-industry relationships drive economic growth. Research Policy, 35 (10), 1499-1508, http://dx.doi. org/10.1016\%2Fj.respol.2006.09.023

OECD - Eurostat Entrepreneurship Indicators Program (2008). Measuring entrepreneurship: A digest of indicators. Last available January 24, 2013 at http://www.oecd.org/industry/entrepreneurshipandbusinessstatistics/41664409.pdf

Pete, Ş., Nagy, Á., Györfy, L.-Z., Benyovszki, A., \& Petru, T. P. (2010). The Evolution of Early-Stage Entrepreneurial Activity Influencing Factors in Romania. Theoretical \& Applied Economics, 17 (7), 5-14.

Rasmussen, E. A. \& Sørheim, R. (2006). Action-based entrepreneurship education. Technovation, 26 (2), 185-194.

Reynolds, P. D., Storey, D. J. \& Westhead, P. (1994). Cross-national Comparisons of the Variation in New Firm Formation Rates. Regional Studies, 28 (4), 443-456, http://dx.doi.org/10.1080\% 2F00343409412331348386

Schultz, T. P. (1990). Women's changing participation in the labor force: a world perspective. Economic Development and Cultural Change, 38 (3), 457-488, http://dx.doi.org/10.1086\%2F451811

Sohn, S. Y. \& Lee, A. S. (2013). Bayesian network analysis for the dynamic prediction of early stage entrepreneurial activity index. Expert Systems with Applications, 40 (10), 4003-4009, http:// dx.doi.org/10.1016\%2Fj.eswa.2013.01.009

Storey, D. J. (1999). Six steps to heaven: evaluating the impact of public policies to support small business in developed economies. In D. L. Sexton and H. Landström, (eds.), Handbook of Entrepreneurship (176-194). Oxford: Blackwell.

Thurik, A. R. (2003). Entrepreneurship and unemployment in the UK. Scottish Journal of Political Economy, 50 (3), 264-290, http://dx.doi.org/10.1111\%2F1467-9485.5003001
Thurik, A. R., Carree, M. A., van Stel, A. \& Audretsch, D. B. (2008). Does self-employment reduce unemployment? Journal of Business Venturing, 23 (6), 673-686, http://dx.doi. org/10.1016\%2Fj.jbusvent.2008.01.007

Van den Bergh, J. C. J. M. (2009). The GDP paradox. Journal of Economic Psychology, 30 (2), 117-135, http://dx.doi. org/10.1016/j.joep.2008.12.001

Van der Sluis, J., van Praag, M. \& Vijverberg, W. (2005). Entrepreneurship Selection and Performance: A Meta-Analysis of the Impact of Education in Developing Economies. The World Bank Economic Review, 19 (2), 224-261, http://dx.doi. org/10.1093\%2Fwber\%2Flhi013

Venkataraman, S. (2004). Regional transformation through technological entrepreneurship. Journal of Business Venturing, 19 (1), 153-167, http://dx.doi.org/10.1016\%2Fj.jbusvent.2003.04.001

Verheul, I., Wennekers, S., Audretsch, D. \& Thurik, R. (2001). An eclectic theory of entrepreneurship: policies, institutions and culture. Tinbergen Institute Discussion Paper TI 2001-030/3.

Witt, U. (2000). Changing Cognitive Frames - Changing Organizational Forms: An Entrepreneurial Theory of Organizational Development. Industrial and Corporate Change, 9 (4), 733-755, http://dx.doi.org/10.1093\%2Ficc\%2F9.4.733

Wong, P. K., Ho, Y.P. \& Autio, E. (2005). Entrepreneurship, Innovation and Economic Growth: Evidence from GEM data. Small Business Economics, 24 (3), 335-350, http://dx.doi.org/10 $.1007 \%$ Fs $11187-005-2000-1$

Yu, T. F. (1998). Adaptive Entrepreneurship and the Economic Development of Hong Kong. World Development, 26(5), 897-911, http://dx.doi.org/10.1016\%2FS0305-750X\%2898\%2900013-8

Miha Marič graduated in 2006 and in the following year (2007) received his master's degree at the Faculty of Economics, University of Ljubljana. He is currently employed as a teaching assistant at the Faculty of Organizational Sciences University of Maribor and is currently concluding his Ph.D. studies at the Faculty of Economics, University of Ljubljana. His research interests are: power, leadership, organizational behavior, HRM, management, organization.

Jasmina Žnidaršič graduated in Marketing and marketing communications at the Faculty of Social Sciences in 2005 and in 2007 received her master's degree in International relations at London Metropolitan University, London. She is currently employed as an assistant in the Department of Human Resource Systems at the Faculty of Organizational Sciences, University of Maribor.

Miha Uhan graduated in management at the Faculty of Economics, University of Ljubljana in 2008. He attended the Joszef study Program at the Vienna University of Economics and Business in 2009 and received his master's degree at the Faculty of Economics, University of Ljubljana in 2010 . He is currently employed as a young researcher at the Faculty of Economics, University of Ljubljana, where he is also enrolled as a doctoral student.

Vlado Dimovski is a full professor of management and organization at the Faculty of Economics, University of Ljubljana. His research interests are: strategic management, organizational learning, competitiveness, developing 
knowledge-based organization, and labor market issues. Dimovski has received his B.A. degree in economics and philosophy, and M.A. in economics from University of Ljubljana, and Ph.D. in management and finance from Cleveland state University. He was state secretary for industry in the government of Slovenia (1995-1997), president of the center for international competitiveness (1997-2000), and minister for labor, family, and social affairs (2000-2004). Dimovski has also wide experience in consulting for numerous companies, institutions, and governments, particularly on the issues of strategic management, labor market, mergers and acquisitions, and the EU-related issues. As an academician Dimovski has taught and researched at the various universities and institutions, and has published in recognized journals.

Marko Ferjan is a full professor at the University of Maribor's Faculty of Organizational Sciences. He received his master's degree and doctorate at the University of Maribor. His areas of research include HRM, communication processes in organizations and educational planning. Currently he is a dean of Faculty of Organizational Sciences, University of Maribor.

Maja Djurica has Ph.D. in organizational sciences. She is a professor of Marketing and Marketing services at Belgrade Busineess School - Higher education institution for applied studies. Her main areas of research interest are Marketing, Marketing Services, Financial Marketing Services and Marketing Research.

Mitja Jeraj is a Ph.D. candidate on Faculty of Economics, University of Ljubljana. His main research interests include entrepreneurship as a broad field of research, entrepreneurial curiosity and other entrepreneurial personalities, relations between entrepreneurship and economic growth, relations between entrepreneurship and unemployment, connection between entrepreneurship and development of sport etc. His research focuses also on management at small and medium enterprises, on cost management and on development of the organization over the time. He has authored and co-authored and present papers on conferences and published papers in scientific journals.

Matej Janežič is a Ph.D. candidate at the Faculty of Economics, University of Ljubljana. His main research interest is to study management in business, with particular interest on learning organizations. His recent research efforts involve development of FUTURE-O® - DYN model for modeling a learning organization as a molecule to become a learning organization using computer simulation techniques. He has also coauthored several research papers focused on Management and is regular presenter at respectful international and national scientific conferences. 